- Graduate in Dentistry. State University of Montes Claros (Unimontes), Montes Claros, Minas Gerais, Brazil.

-Professor, Department of Dentistry, State University of Montes Claros (Unimontes), Montes Claros, Minas Gerais, Brazil.

${ }^{3}$ Professor, Federal University of Alfenas (Unifal), Alfenas, Minas Gerais, Brazil.
Corresponding author:

Samuel Trezena

Rua Pedro Ferreira, n० 97 .

Santa Lúcia I. Montes Claros,

Minas Gerais, Brazil.

Telefone: 38 9 9174-9401

e-mail: samueltrezena@gmail.com

Received: July 22, 2018

Accepted: December 12, 2018

\section{Profile evaluation of patients diagnosed with non-neoplastic proliferative lesions in a dentistry clinic}

\author{
Gabriela Medeiros da Cruz', Samuel Trezena ${ }^{1, *}$, \\ Lívia Máris Ribeiro Paranaíba ${ }^{3}$, Daniella Reis \\ Barbosa Martelli², Mario Rodrigues de Melo Filho², \\ Sabina Pena Borges Pêgo²
}

Non-neoplastic proliferative lesions (NNPLs) are alterations that affect oral mucosal tissues. The etiology of these lesions is associated with local irritantprocesses, principallyinflammation, infections and mechanical irritants. NNPLs are classified into four groups: inflammatory fibrous hyperplasia, pyogenic granuloma, peripheral ossifying fibroma, and peripheral giant cell lesion. Aim: This cross-sectional, quantitative, retrospective, analytical, informative and educational study aimed to evaluate the profiles of patients who were diagnosed with any nonneoplastic proliferative lesion in the Unimontes Stomatology Clinic, Brazil. Methods: From January 2001 to June 2012, 1505 patients were counted who underwent anatomopathological examination, in addition to evaluations for other conditions. Results: Of these 1505 patients, 223 were diagnosed with some type of non-neoplastic proliferative lesion, and statistical analysis showed that $76 \%$ were female and $24 \%$ male and that $23.3 \%$ were between 41 and 50 years of age. Inflammatory fibrous hyperplasia was the most common NNPL (86.5\%). Conclusion: Due to the high frequency of these lesions in the dental clinic, this type of survey has significant relevance for informing health professionals about these proliferative processes. This information is necessary, since the dentist is intimately involved in both the etiology, treatment and prevention of these lesions.

Keywords: Gingival Hyperplasia. Pyogenic Granuloma. Hyperplasia. 


\section{Introduction}

Non-neoplastic proliferative lesions (NNPLs) are alterations that affect the oral mucosal tissues. The etiology of these lesions is associated with local irritant processes, principally inflammation, infections and mechanical irritants (such as the use of badly adapted prostheses, overhanging dental restorations and the presence of bacterial plaque). In most cases, these lesions occur in the jugal mucosa, in the leukoderm, of female individuals between the fourth and fifth decades of life $e^{1,2}$.

NNPLs are classified into four groups: inflammatory fibrous hyperplasia, pyogenic granuloma, peripheral ossifying fibroma, and peripheral giant cell lesion ${ }^{3-6}$. The fibrous hyperplasia $(\mathrm{FH})$ is mostly caused by chronic trauma due to the use of badly adapted partial or complete dentures. Among the NNPLs, it is the most commonly found in clinical practice, asymptomatic and presents with a color similar to healthy mucosa. It is commonly found between the third and sixth decades of life, and its treatment consists of surgical excision $7-9$.

Pyogenic granuloma (PG) is visualized as an exophytic mass that is usually found in the vestibular gums of women, which varies in color from reddish to purple, with the possibility of spontaneous bleeding due to its greater vascularization. When it affects pregnant women, it is a denominated gravidarum tumor, and it is able to regress spontaneously after gestation $5,6,10$. The peripheral ossifying fibroma (POF) and the peripheral giant cell lesion (PGCL) exclusively affect the gingival mucosa and/or alveolar ridge and are the least prevalent NNPL types, in addition to being the only ones that can present on radiography ${ }^{11,12}$.

The final diagnosis is obtained by histopathological examination of the lesion, which is surgically excised ${ }^{8}$. The present article was justified to evaluate the profiles of patients who were diagnosed with NNPLs during a 12-year period in the stomatology clinic of the dentistry course at the State University of Montes Claros-Unimontes.

\section{Materials and Methods}

This was a cross-sectional, quantitative, retrospective, analytical, informative and educational study. Information was collected from all the clinical records of the patients who were attended at the clinic of stomatology of the dentistry course of the State University of Montes Claros - Unimontes, Minas Gerais, Brazil, from January 2001 to June 2012.

Of the 1505 patient files analyzed, 223 patients were selected who met the inclusion criteria: submission for surgical removal of the lesions, followed by a pathology examination in addition to complete clinical record data. The exclusion criteria were patients who did not obtain answers regarding the final diagnosis through the anatomopathological report and who presented incomplete medical records regarding the studied variables.

The following features was evaluated: sex, age, skin color (leukoderm, feoderm, melanoderm), occupation, origin (rural or urban zone), naturality, lesion location and extent, number of lesions, diagnostic hypotheses, the results of the anatomopathological 
report, treatment instituted, deleterious habits (alcoholism, smoking and use of illicit drugs), use of prostheses (total or partial) and oral hygiene conditions of the patients.

The data were evaluated using the SPSS(B) program (Statistical Package for the Social Science), version 18.0, for Windows, and were subjected to specific statistical analyses. Descriptive analyses and chi-square tests were performed using a bivariate analysis, with a level of significance lower than 0.005 . This study was approved by the Ethics Committee in Research of the State University of Montes Claros (UNIMONTES) for the opinion of $n^{\circ} 023 / 2012$.

\section{RESULTS}

\section{General Characteristics of the sample}

Of the patients who were attended at the Dentistry Clinic of the State University of Montes Claros - Unimontes, over the 12-year period (January 2001 to June 2012), one could observe the high prevalence of NNPLs identified (223 patients). Most of the patients were female (76.6\%); only $23.4 \%$ were male. Most (23.3\%) patients were affected between the fourth and sixth decades of life (Figure 1). The most prevalent manifestation was fibrous hyperplasia (86.5\%), followed by pyogenic granuloma (13.5\%). There were no results regarding peripheral ossifying fibroma and peripheral lesions of giant cells.

Regarding skin color, $65.9 \%$ were feoderms, followed by $16.6 \%$ melanoderms, $13 \%$ leukoderms and $4.5 \%$ unknown. Regarding deleterious habits, $3.1 \%$ were alcoholics, $90.6 \%$ were not alcoholics, and $1.3 \%$ were ex-alcoholics; $10.8 \%$ were confirmed to be smokers, $75.8 \%$ were not smokers and $10.8 \%$ reported being ex-smokers. A relevant percentage of the subjects smoked a longer period of time and a greater daily amount of tobacco.

Of the patients who searched for the service, $91 \%$ presented only one lesion, $7.2 \%$ had two lesions and less than $1 \%$ had three or more lesions. Of the total number, most (30.9\%) lesions had an average diameter up to $5 \mathrm{~mm}$ (Figure 2). Regarding location, $22 \%$ were found in the jugal mucosa (Figure 3 ).

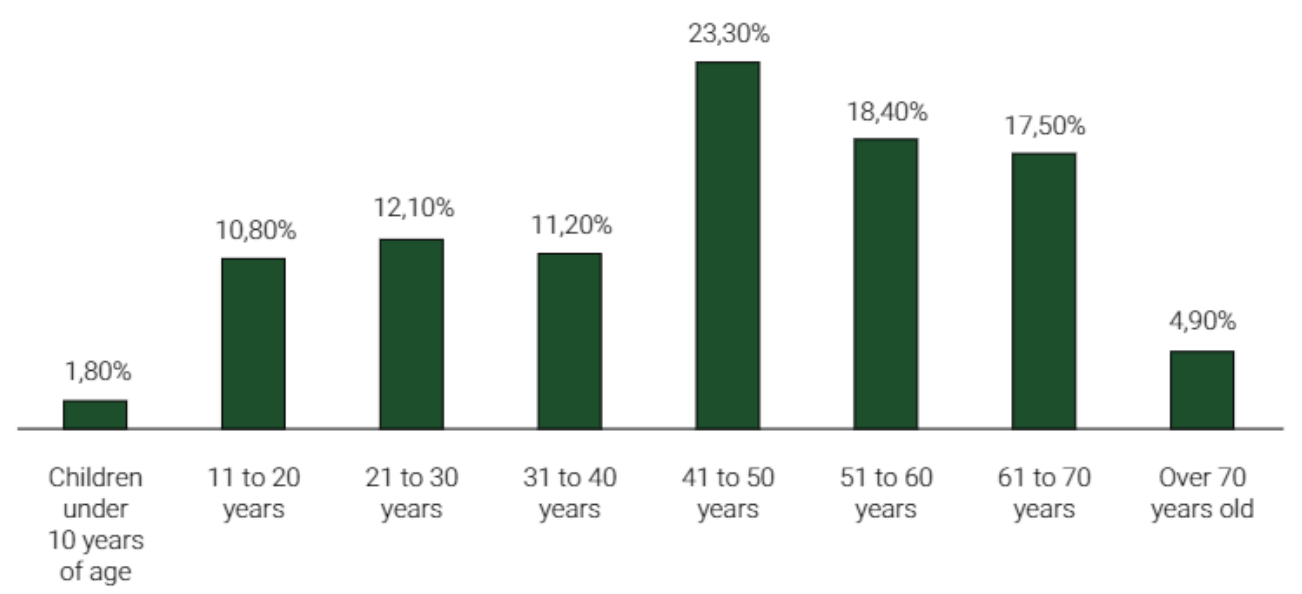

Figure 1. Distribution by age of treated patients with non-neoplastic proliferative lesions. 


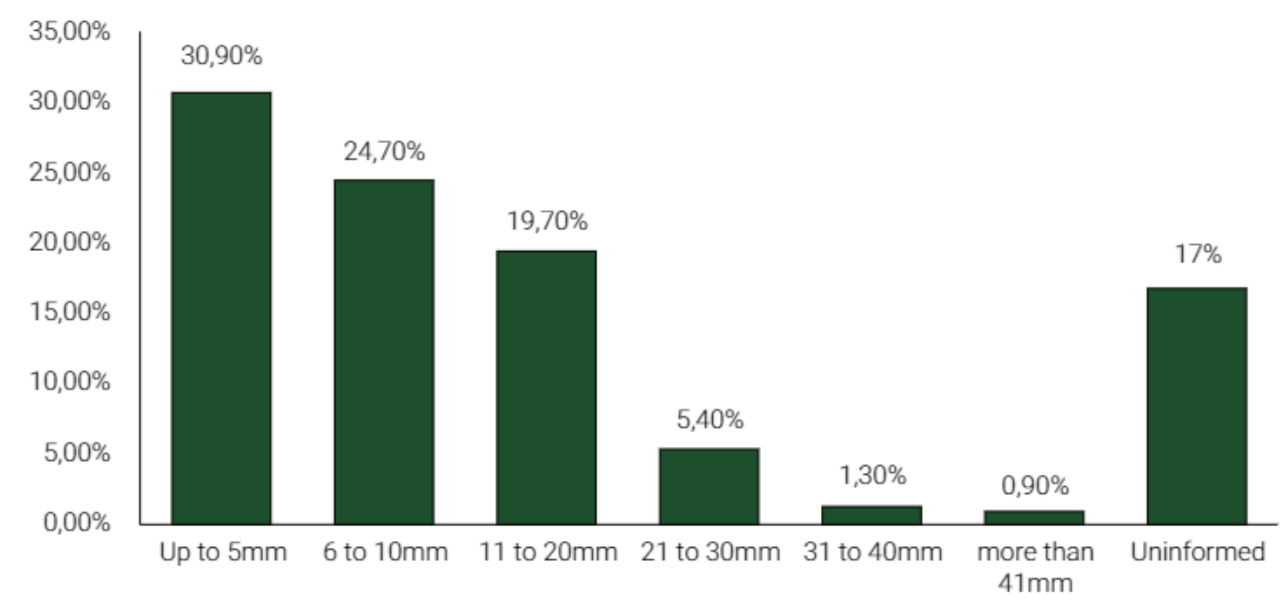

Figure 2. Extension of non-neoplastic proliferative lesions.

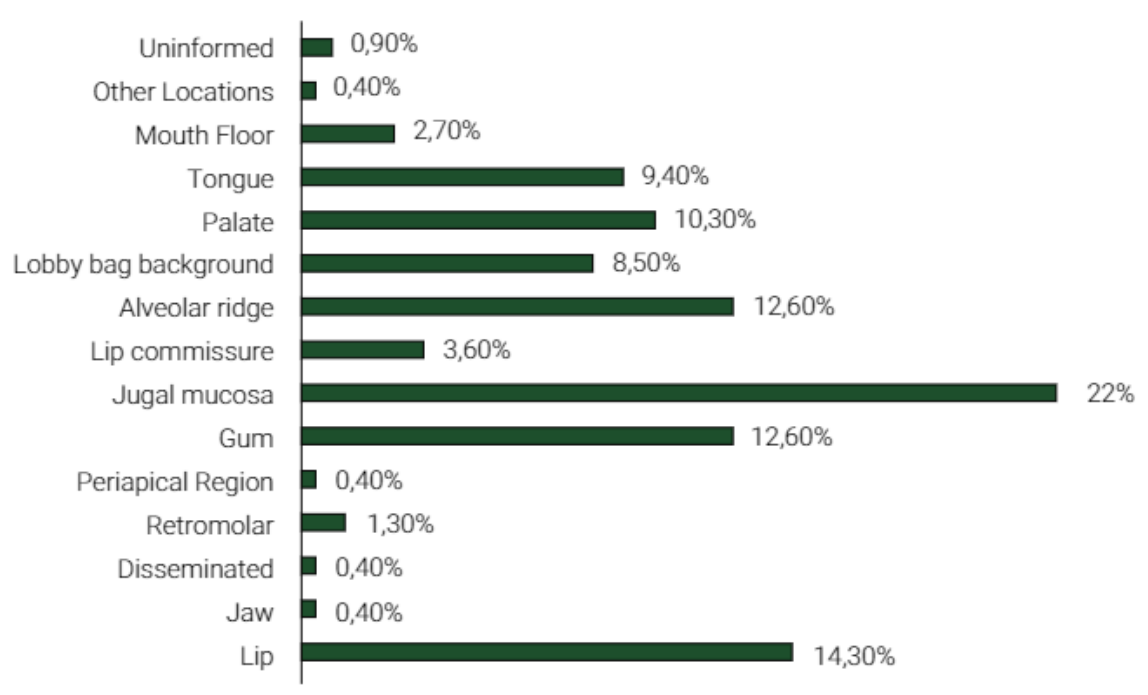

Figure 3. Location affected by non-neoplastic proliferative lesions.

Among the patients, $52.9 \%$ used prosthetics, $44.4 \%$ did not use prosthetics and $2.7 \%$ did not report their use. Regarding oral hygiene, $42.2 \%$ were considered good, followed by $35.9 \%$ who were considered bad, $17 \%$ regular and $4.9 \%$ not informed. The predominant treatment for lesions was surgical excision, observed in $93.7 \%$ of the sample. Only $1.3 \%$ of the patients were followed up to periodically evaluate the regression of the lesions, $0.9 \%$ were referred and $4 \%$ underwent other types of unspecified treatments.

\section{Bivariate Analyses}

Of the four groups of non-neoplastic proliferative lesions, only fibrous hyperplasia and pyogenic granuloma were diagnosed. Data regarding the final diagnosis with clinical characteristics identified in the sample are shown in Table 1. Significance was obtained at the intersection of the variables gender and location for the lesions $(p<0.005)$. 
Table 1. Correlation between the final diagnosis with clinical characteristics in the sample.

\begin{tabular}{|c|c|c|c|c|}
\hline & & Fibrous hyperplasia & Pyogenic granuloma & \\
\hline & & $\mathrm{n}(\%)$ & $\mathrm{n}(\%)$ & $p$ \\
\hline \multirow{2}{*}{ Sex } & Male & $45(23.4)$ & $7(23.3)$ & \multirow{2}{*}{0.001} \\
\hline & Female & $148(76.6)$ & $23(76.7)$ & \\
\hline \multirow{8}{*}{ Age } & Less than 10 & $3(1.5)$ & $1(3.3)$ & \multirow{8}{*}{0.017} \\
\hline & 11 to 20 years & $18(9.3)$ & $6(20)$ & \\
\hline & 21 to 30 years & $19(9.8)$ & $8(26.7)$ & \\
\hline & 31 to 40 years & $21(10.8)$ & $4(13.3)$ & \\
\hline & 41 to 50 years & $47(24.35)$ & $5(16.7)$ & \\
\hline & 51 to 60 years & $41(21.25)$ & $0(0.0)$ & \\
\hline & 61 to 70 years & $35(18.2)$ & $4(13.3)$ & \\
\hline & More than 71 & $9(4.8)$ & $2(6.7)$ & \\
\hline \multirow{9}{*}{ Occupation } & Student & $17(8.9)$ & $6(20)$ & \multirow{9}{*}{0.563} \\
\hline & Rural worker & $21(10.9)$ & $1(3.3)$ & \\
\hline & Retired & $27(14)$ & $3(10)$ & \\
\hline & Public server & $16(8.1)$ & $2(6.7)$ & \\
\hline & Self Employed & $27(14)$ & $5(16.7)$ & \\
\hline & From home & $37(18.9)$ & $6(20)$ & \\
\hline & Unemployed & $2(1.05)$ & $1(3.3)$ & \\
\hline & Uninformed & $22(11.2)$ & $2(6.7)$ & \\
\hline & Other categories & $24(12.3)$ & $4(13.3)$ & \\
\hline \multirow{4}{*}{ Skin color } & Leukoderm & $27(14)$ & $2(6.7)$ & \multirow{4}{*}{0.058} \\
\hline & Feoderm & $130(67.3)$ & $17(56.7)$ & \\
\hline & Melanoderm & $27(14)$ & $10(33.3)$ & \\
\hline & Uninformed & $9(4.7)$ & $1(3.3)$ & \\
\hline \multirow{4}{*}{ Lesions number } & One & $174(90.1)$ & $29(96.7)$ & \multirow{4}{*}{0.693} \\
\hline & Two & $15(7.8)$ & $1(3.3)$ & \\
\hline & Three & $2(1.05)$ & $0(0.0)$ & \\
\hline & Uninformed & $2(1.05)$ & $0(0.0)$ & \\
\hline \multirow{15}{*}{ Location } & Lip & $27(14)$ & $5(16.7)$ & \multirow{15}{*}{$<0.001$} \\
\hline & Jaw & $1(0.48)$ & $0(0.0)$ & \\
\hline & Disseminated & $1(0.48)$ & $0(0.0)$ & \\
\hline & Retromolar & $3(1.5)$ & $0(0.0)$ & \\
\hline & Periapical region & $1(0.48)$ & $0(0.0)$ & \\
\hline & Gum & $11(5.7)$ & $17(56.7)$ & \\
\hline & Jugal mucosa & $45(23.4)$ & $4(13.3)$ & \\
\hline & Lip commissure & $7(3.6)$ & $1(3.3)$ & \\
\hline & Alveolar ridge & $27(14)$ & $1(3.3)$ & \\
\hline & Lobby fund & $19(9.8)$ & $0(0.0)$ & \\
\hline & Palate & $22(11.2)$ & $1(3.3)$ & \\
\hline & Tongue & $20(10.6)$ & $1(3.3)$ & \\
\hline & Mouth Floor & $6(3.1)$ & $0(0.0)$ & \\
\hline & Others locations & $1(0.48)$ & $0(0.0)$ & \\
\hline & Uninformed & $2(1.05)$ & $0(0.0)$ & \\
\hline
\end{tabular}




\begin{tabular}{llcc}
\hline & Up to $5 \mathrm{~mm}$ & $61(31.6)$ & $8(26.7)$ \\
\cline { 2 - 4 } & 6 to $10 \mathrm{~mm}$ & $49(25.4)$ & $6(20)$ \\
\cline { 2 - 4 } Lesion & 11 to $20 \mathrm{~mm}$ & $39(20.20)$ & $5(16.7)$ \\
\cline { 2 - 4 } Extension & 21 to $30 \mathrm{~mm}$ & $10(5.20)$ & $2(6.7)$ \\
\cline { 2 - 4 } & 31 to $40 \mathrm{~mm}$ & $2(1.05)$ & $1(3.3)$ \\
\cline { 2 - 4 } & More than $41 \mathrm{~mm}$ & $2(1.05)$ & $0(0.0)$ \\
\cline { 2 - 4 } & Uninformed & $30(15.5)$ & $8(26.7)$ \\
\hline
\end{tabular}

* $p$-value according to chi-square test $(p<0.005)$.

Table 2. Correlation between the non-neoplastic proliferative lesions and their risk factors.

\begin{tabular}{|c|c|c|c|c|}
\hline & & Fibrous hyperplasia & Pyogenic granuloma & \multirow{2}{*}{$p$} \\
\hline & & $\mathrm{n}(\%)$ & $\mathrm{n}(\%)$ & \\
\hline \multirow{3}{*}{$\begin{array}{l}\text { Use of illicit } \\
\text { drugs }\end{array}$} & Yes & $1(0.49)$ & $0(0.0)$ & \multirow{3}{*}{0.914} \\
\hline & No & $137(70.1)$ & $21(70)$ & \\
\hline & Uninformed & $55(29.41)$ & $9(30)$ & \\
\hline \multirow{4}{*}{ Alcoholism } & Yes & $7(3.6)$ & $0(0.0)$ & \multirow{4}{*}{0.308} \\
\hline & No & $172(89.2)$ & $30(100)$ & \\
\hline & Ex & $3(1.5)$ & $0(0.0)$ & \\
\hline & Uninformed & $11(5.7)$ & $0(0.0)$ & \\
\hline \multirow{4}{*}{ Smoking } & Yes & $23(12.1)$ & $1(3.3)$ & \multirow{4}{*}{0.550} \\
\hline & No & $144(74.6)$ & $25(83.4)$ & \\
\hline & Ex & $21(10.8)$ & $3(10)$ & \\
\hline & Uninformed & $5(2.5)$ & $1(3.3)$ & \\
\hline \multirow{3}{*}{$\begin{array}{l}\text { Use of } \\
\text { prosthesis }\end{array}$} & Yes & $109(56.5)$ & $9(30)$ & \multirow{3}{*}{0.025} \\
\hline & No & $79(40.9)$ & $20(66.7)$ & \\
\hline & Uninformed & $5(2.6)$ & $1(3.3)$ & \\
\hline \multirow{4}{*}{ Oral Hygiene } & Good & $84(43.5)$ & $10(33.3)$ & \multirow{4}{*}{0.708} \\
\hline & Regular & $33(17.1)$ & $5(16.7)$ & \\
\hline & Bad & $67(34.7)$ & $13(43.3)$ & \\
\hline & Uninformed & $9(4.7)$ & $2(6.7)$ & \\
\hline
\end{tabular}

${ }^{\star} p$-value according to chi-square test $(p<0.005)$.

Table 2 shows the statistical data in relation to the final diagnosis of the lesions that underwent pathological examination with the risk factors evaluated herein. A large majority of the patients reported not having deleterious habits such as alcoholism and smoking, and statistical significance regarding the variables in question was lacking (illicit drug use, alcoholism, smoking, prosthesis use and oral hygiene).

Regarding the statistical findings, statistical significance was observed between the risk factors for the appearance of non-neoplastic proliferative lesions between the variables "sex" and "smoking" (0.001) and "sex" and "oral hygiene habits" (0.002). The variables "age" and "occupation" were also predisposing factors for the variable "use of prostheses" (<0.001) (Table 3). 
Table 3. Correlation between the clinical characteristics of patients with variables related to risk factors for non-neoplastic proliferative lesions.

\begin{tabular}{|c|c|c|c|c|c|c|c|c|c|}
\hline & & \multirow{3}{*}{$\mathrm{n}$} & \multirow{3}{*}{$\%$} & \multicolumn{6}{|c|}{ Risk factors } \\
\hline & & & & $\begin{array}{c}\text { Use of } \\
\text { prosthesis }\end{array}$ & Alcoholism & Smoking & $\begin{array}{l}\text { Use of } \\
\text { illicit } \\
\text { drugs }\end{array}$ & $\begin{array}{c}\text { Oral } \\
\text { Hygiene }\end{array}$ & $\begin{array}{l}\text { Number of } \\
\text { lesions }\end{array}$ \\
\hline & & & & \multicolumn{6}{|c|}{ p value* } \\
\hline Sex & $\begin{array}{l}\text { Masculine } \\
\text { Female }\end{array}$ & $\begin{array}{c}52 \\
171 \\
\end{array}$ & $\begin{array}{l}23,3 \% \\
76,7 \% \\
\end{array}$ & 0.057 & 0.674 & $<0.001$ & 0.186 & 0.002 & 0.698 \\
\hline Age & $\begin{array}{l}\text { Less than } 10 \\
11 \text { to } 20 \text { years } \\
21 \text { to } 30 \text { years } \\
31 \text { to } 40 \text { years } \\
41 \text { to } 50 \text { years } \\
51 \text { to } 60 \text { years } \\
61 \text { to } 70 \text { years } \\
\text { More than } 71\end{array}$ & $\begin{array}{l}4 \\
24 \\
27 \\
25 \\
52 \\
41 \\
39 \\
11\end{array}$ & $\begin{array}{c}1,8 \% \\
10,8 \% \\
12,1 \% \\
11,2 \% \\
23,3 \% \\
18,4 \% \\
17,5 \% \\
4,9 \% \\
\end{array}$ & $<0.001$ & 0.674 & 0.068 & 0.411 & 0.151 & 0.303 \\
\hline Skin color & $\begin{array}{l}\text { Leukoderm } \\
\text { Feoderm } \\
\text { Melanoderm } \\
\text { Uninformed }\end{array}$ & $\begin{array}{c}29 \\
147 \\
37 \\
10 \\
\end{array}$ & $\begin{array}{c}13 \% \\
65,9 \% \\
16,6 \% \\
4,5 \% \\
\end{array}$ & 0.132 & 0.242 & 0.611 & 0.353 & 0.269 & 0.655 \\
\hline Occupation & $\begin{array}{c}\text { Student } \\
\text { Rural worker } \\
\text { Retired } \\
\text { Public server } \\
\text { Self Employed } \\
\text { From home } \\
\text { Unemployed } \\
\text { Uninformed } \\
\text { Other categories }\end{array}$ & $\begin{array}{l}23 \\
22 \\
30 \\
18 \\
32 \\
43 \\
3 \\
24 \\
28\end{array}$ & $\begin{array}{c}10,3 \% \\
9,9 \% \\
13,5 \% \\
8,1 \% \\
14,3 \% \\
19,3 \% \\
1,3 \% \\
10,8 \% \\
12,6 \% \\
\end{array}$ & $<0.001$ & 0.925 & 0.019 & 0.848 & 0.402 & 0.602 \\
\hline $\begin{array}{l}\text { Lesions } \\
\text { Number }\end{array}$ & $\begin{array}{c}\text { One } \\
\text { two } \\
\text { Three } \\
\text { Uninformed }\end{array}$ & $\begin{array}{c}203 \\
16 \\
2 \\
2\end{array}$ & $\begin{array}{l}91 \% \\
7,2 \% \\
0,9 \% \\
0,9 \%\end{array}$ & 0.109 & 0.364 & 0.083 & 0.424 & 0.983 & - \\
\hline
\end{tabular}

${ }^{\star} p$-value according to chi-square test $(p<0,005)$.

\section{DISCUSSION}

Fibrous hyperplasia is the most common lesion among the LPNNs ${ }^{3,5,7-9}(67.7 \%$ of the diagnosed lesions in the Unimontes stomatology service, confirmed in $86.5 \%$ ). This condition usually affects women (76\% of the patients analyzed) because they care more about aesthetic factors and are more prone to using orthodontic appliances such as dental prostheses ${ }^{13-14}$.

Peripheral lesions of giant cells among the other NNPL representatives are the least prevalent type, except in a study carried out by Gambino et al. ${ }^{8}$ (2017) in Italy, where this lesion was the second most commonly found among the analyzed biopsy specimens. Manjunatha et al. ${ }^{1}$ reported pyogenic granuloma as the most prevalent lesion.

The most common sites of involvement of these lesions were as follows: gingiva, jugal mucosa, tongue, lips and palate, which do not present predisposition to the maxilla or mandible $7,3,14$. The most common site in our study was the jugal mucosa, which reached statistical significance ( $p<0.001$ ), corresponding to $22 \%$ of cases for fibrous hyperplasia and $56.7 \%$ for pyogenic granuloma. Similar results have been 
reported by Mutarana-Ramirez et al. ${ }^{5}$ (2015) (26.6\%) and Santana-Santos et al. ${ }^{7}$ (61.7\%). Narwal and Bala ${ }^{4}$ (2017) observed a greater prevalence of gingival lesions (59.15\%), followed by jugal mucosa (14.08\%), as well as Reddy et al. ${ }^{2}$ (2012), at $81.1 \%$ and $8.1 \%$, respectively. Nascimento et al. ${ }^{3}(2016)$ reported that the most affected site was the lips (24.6\%).

According to Koo et al. $(2017)^{10}$, pyogenic granuloma arises predominantly in females (55\%), which may be related to the hormonal alterations of women, especially during pregnancy, with increased levels of endothelial growth factors ${ }^{2,6,13}$. These results are very similar to the present study, in which $76.7 \%$ of the sample diagnosed with pyogenic granuloma was female.

In relation to race, NNPLs present greater involvement in leukodermas, and in a study of Gheno et al. ${ }^{9}$, a prevalence of $89.6 \%$ was found. There is no justification for this result in the literature, but it is believed that the white race has greater access to dental services, and therefore their lesions are more commonly reported ${ }^{15}$. In contrast to the results obtained in the Unimontes Stomatology Clinic, 65\% feodermas were diagnosed with this condition.

The marked propensity of the fourth decade of life to present with the appearance of lesions such as HFI may be associated with the irritative nature of these lesions. At this stage of life, the use of prostheses is common, which were documented in $57 \%$ of the subjects diagnosed with an LPNN ${ }^{5,4,7}$. However, GP diagnosis was more common in the age range from 21 to 30 years due to hormonal factors ${ }^{6}$.

According to Pedron et $a .^{13}$ (2010), the sizes of the lesions may vary, with LPNNs smaller than $1 \mathrm{~cm}$, as well as large lesions that can affect almost the entire mouth, being described. In the present study, we found similar data, since $31.6 \%$ of the lesions were diagnosed as fibrous hyperplasia, and $26.7 \%$ of the pyogenic granulomas had an average size of up to 5 $\mathrm{mm}$ in length. Very few studies have evaluated the extent of the lesions.

According to Pedron et al..$^{13}$ (2010), surgical excision is the most commonly used technique, being performed in $93.7 \%$ of the lesions diagnosed in the Unimontes Clinic. Regardless of the treatment modality chosen, it is essential to refer the material collected for histopathological analysis, confirming the diagnostic hypothesis and providing the correct diagnosis.

In this study, data were collected over a period of 12 years. The sample involved 1505 patients from the Unimontes Stomatology Clinic who were submitted to surgical removal and anatomopathological examination. Of these individuals, the great majority were diagnosed with $\mathrm{FH}(86,5 \%)$, followed by PG (13,5\%). The jugal mucosa (22\%), females $(76,6 \%)$, feodermas $(65,9 \%)$ and patients in their fourth to sixth decade of life $(23,3 \%)$ were the most affected groups.

NNPLs are common lesions in the dental clinic. They present an etiology associated with an initial irritant process, mainly inflammation, infections and mechanical irritants such as badly adapted prostheses. This type of survey has significant relevance for informing health professionals about the occurrence of these proliferative processes. This information is necessary, since the dentist is intimately involved in both the etiology, treatment and prevention of these lesions. Due to the high occurrence, 
the dental surgeon should be aware of these lesions, enabling accurate prevention, diagnosis and appropriate treatment.

\section{REFERENCES}

1. Manjunatha BS, Sutariya R, Nagamahita V, Dholia B, Shah V. Analysis of gingival biopsies in the Gujarati population: A retrospective study. J Cancer Res Ther. 2014 Oct-Dec;10(4):1088-92 doi: 10.4103/0973-1482.137929

2. Reddy V, Saxena S, Saxena S, Reddy M. Reactive hyperplastic lesions of the oral cavity: A ten year observational study on North Indian Population. J Clin Exp Dent. 2012 Jul 1;4(3):e136-40. doi: $10.4317 /$ jced. 50670 .

3. Nascimento JS, Takahama-Júnior A, Pires FR, Barros EMVB, Azevedo RS. Brazilian oral pathology: a retrospective survey of 245 cases from a Surgical Pathology Hospital Laboratory. Braz Dent Sci. 2016;19(2):96-103. doi: 10.14295/bds.2016.v19i2.1195.

4. Narwal A, Bala S. Osteopontin expression and clinicopathological correlation of oral hyperplastic reactive lesions: an institutional 6-year retrospective study. J Oral Maxillofac Pathol. 2017 Sep-Dec;21(3):382-386. doi: 10.4103/jomfp.JOMFP_231_15.

5. Maturana-Ramírez A, Adorno-Farías D, Reyes-Rojas M, Farías-Vergara M, Aitken-Saavedra J. A retrospective analyses of reactive hyperplastic lesions of the oral cavity: study of 1149 cases diagnosed between 2000 and 2011, Chile. Acta Odontol Latinoam. 2015;28(2):103-7. doi: 10.1590/S1852-48342015000200002.

6. Wollina U, Langner D, França K, Gianfaldoni S, Lotti T, Tchernev G. Pyogenic Granuloma - a common benign vascular tumor with variable clinical presentation:new findings and treatment options. Open Access Maced J Med Sci. 2017 Jul 13;5(4):423-426. doi: 10.3889/oamjms.2017.111.

7. Santana-Santos T, Martins-Filho PR, Piva MR, Souza Andrade ES. Focal fibrous hyperplasia: A review of 193 cases. J Oral Maxillofac Pathol. 2014 Sep;18(Suppl 1):S86-9. doi: 10.4103/0973-029X.141328.

8. Gambino A, Carbone M, Broccoletti R, Carcieri P, Conrotto D, Carrozzo M, et al. A reporto on the clinical-pathlogical correlations of 788 gingival lesions. Med Oral Patol Oral Cir Bucal. 2017 Nov 1;22(6):e686-e693. doi: 10.4317/medoral.21845.

9. Gheno JN, Martins MAT, Munerato MC, Hugo FN, Sant’ana Filho M, Weissheimer C, et al. Oral mucosal lesions and their association with sociodemographic, behavioral, and health status factors. Braz Oral Res. 2015;29. pii: S1806-83242015000100289. doi: 10.1590/1807-3107BOR-2015.vol29.0093.

10. Koo MG, Lee SH, Han SE. Pyogenic Granuloma: a retrospective analyses of cases treated over a 10-year. Arch Craniofac Surg. 2017 Mar;18(1):16-20. doi: 10.7181/acfs.2017.18.1.16.

11. Nazareth B, Arya H, Arora SAR, Arora R. Peripheral Ossifying Fibroma - a clinical report. Int J Odontostomat. 2011;5(2):153-6.

12. Henriques PSG, Okajima LS, Nunes MP, Montalli VAM. Coverage root after removing peripheral ossifying fibroma: 5-year follow-up case report. Case Rep Dent. 2016;2016:6874235

13. Pedron IG, Utumi ER, Tancredi ARC, Perez FEG, Marcucci G. Non-neoplastic proliferative gingiva processes in patients undergoing orthodontic treatment. Dental Press J Orthod. 2010 Nov-Dec;15(6):80-7.

14. Casian Romero A, Trejo Queiroz P, de Leon Torres C, Carmona Ruiz D. Inflammatory fibrous hyperplasia: case report. Rev Clin Periodonc Implantol. Rehabil. Oral. 2011;4(2):74-9. doi: 10.4067/S0719-01072011000200007.

15. Amadei SU, Pereira AC, Silveira VAS, Carmo ED, Scherma AP, Rosa LEB. Prevalence of non neoplastic proliferative lesions in oral cavities: a forty-year retrospective study. Clin Pesq Odontol UNITAU. 2009; 1(1):38-42 